UDC 81'371:81-115

DOI https://doi.org/10.32782/tps2663-4880/2021.20.1.19

\title{
THE CONCEPT TRUTH AND ITS SEMANTIC RELATIONS TO THE CONCEPT NOOSPHERE MIND
}

\section{КОНЦЕПТ ІСТИНА ТА ЙОГО СЕМАНТИЧНІ ЗВ'ЯЗКИ 3 КОНЦЕПТОМ НООСФЕРНИЙ РОЗУМ}

\author{
Stefanova N.O., \\ orcid.org/0000-0002-8699-9219 \\ Doctor of Philology, Associate Professor, \\ Professor at the Professor O. M. Morokhovsky Department of English Philology Translation \\ and Philosophy of Language \\ Kyiv National Linguistic University
}

The dynamic changes that have manifested in the biosphere over the past thousand years in connection with the growth of scientific thought and the social activity of humanity have never been noted before. The human task is to deliver the most significant possible benefit to others. It becomes clear that the development of humanity can be achieved by various means, one of which is science. Any deed is correct and harmonious with the common good when it results from the work of many people who can think.

The noosphere mind combines ecological, global, universal and cultural values of civilized humanity, eliminating the opposition of man and nature, providing a stimulus to the moral and ethical evolution of planetary life in unity with nature. The modern anthropocosmic worldview denies the consumer's attitude to nature as an environment without which fundamental worldview values cannot be formed in every culture.

The article is devoted to studying semantic connections between the fundamental value concept TRUTH and the concept NOOSPHERIC MIND, which is associated with the current stage of development of the biosphere and is the evolutionary stage of human development as a whole. Using the method of diachronic commentary on etymological versions of the primary meanings of the lexemes truth, belief, faith, noosphere mind in the English-language etymological sources, it is analysed the verbal semantic state of lexemes based on reconstructed etymons. The semantic lexeme truth, belief, faith, noosphere mind are studied. Semantic correlations of these lexemes are revealed, and it is stated that they consist in common semes of "intellectual phenomenon encompassing motivational and cognitive systems", "harmony", "order", "honest intentions", "desires", in the moral and spiritual component - "a religious concept" or "Christian science", "God". It is formulated that the noosphere and the NOOSPHERE MIND create new feelings and values; however, there is a place for global universal values, among which the TRUTH is.

Key words: linguoconceptology, value concept TRUTH, evolutionary concept NOOSPHERIC MIND, semantic structure.

Динамічні зміни, які виявляються в біосфері протягом останніх тисячі років у зв'язку зі зростанням наукової думки та соціальної діяльності людства, не були відзначені ніколи раніше. Завдання людини полягає в доставленні якомога більшої користі оточуючим. Маючи на меті розвиток людства, стає зрозумілим, що воно досягається різними засобами, одним із яких $є$ наука. Наскільки вчинки $є$ правильними, гармонійними й корелюються із загальним благом, визначається результатом роботи великої кількості людей, які можуть мислити.

Ноосфрерний розум поєднує екологічну, глобальну, загальнолюдську й культурну ціннісні свідомості цивілізованого людства, нівелює протиставлення людини і природи, надаючи стимул до морально-етичної еволюції планетарного життя в єдності з природою. Сучасний антропокосмічний світогляд заперечує споживацьке ставлення до природи як середовища, без якого не можуть формуватися засадничі світоглядні цінності в кожній культурі.

Стаття присвячена дослідженню семантичних зв'язків фундаментального ціннісного концепту TRUTH і концепту НООСФЕРНИЙ РОЗУМ, що пов'язаний із сучасною стадією розвитку біосфери і становить еволюційний етап розвитку людства в цілому. За допомогою методу діахронічного коментаря етимологічних версій первісних значень лексем truth, belief, faith, noosphere mind в англійськомовних етимологічних джерелах проаналізовано прамовний семантичний стан лексем на основі реконструйованих етимонів. Досліджено семантичну структуру лексем truth, belief, faith, noosphere mind і виявлено семантичні кореляції зазначених лексем, які полягають у спільних семах «інтелектуальне явище, що охоплює мотиваційні та когнітивні системи», «гармонія», «порядок», «чесні наміри», «бажання», у морально-духовному складнику - «релігійна концепція» чи «християнська наука», «Бог». Сформульовано ідею, що ноосфера й НООСФЕРНИЙ РОЗУМ створюють нові відчуття та цінності, однак серед них $€$ місце для глобальних загальнолюдських цінностей, однією з яких є ICTИНА.

Ключові слова: лінгвоконцептологія, ціннісний концепт TRUTH, еволюційний концепт НООСФЕРНИЙ РОЗУМ, семантична структура.

Introduction. Linguoconceptology, as a new branch of cognitive linguistics in the late twentieth century, aims to study the processes of conceptualization of the world, substantiation of the concept and definition of its structure, presentation of a sin- gle universal system of linguoconcepts through the definition of individual concepts and national conceptospheres and their comparison. According to S.G. Vorkachev, the current relevance of this scientific discipline is determined by the presence of cer- 
tain "supertasks" in linguoconceptological studies. These tasks identify (confirm or refute) data on the structure and content of the national mentality of a particular language culture, which distinguishes it from classical science, mainly structural linguistics, focused on the autonomous description of the human language system [4 p. 17-18]. We also agree with the researcher that linguoconceptology is perhaps the most contemporary direction, and the concept continues to be a particular "password" term, the active functioning of which in scientific works, according to its supporters and users, demonstrates further scientific "perspective" of its study. Further, assessing the nature and status of linguoconceptology, the researcher defines it as a formed and mature scientific field, as evidenced by the presence of a categorical apparatus and developed methodological algorithms of the concepts research [4, p. 4].

In order to organize the set of concepts at the level of systemic relations, or conceptosphere, it is necessary, in our opinion, to take into account not only the semantic organization of this sphere but also its understanding as a mental construct of complex nature. Also justified is the expediency of using the component «sphere» in this terminological formation; it operates on the background of such word-forming terminological analogues as "technosphere", "anthroposphere", "sociosphere", "atmosphere", "Stratosphere" and which academician V.I. Vernadsky united under one term "noosphere", including in this system man and his activities $[3 ; 8$, p. 76].

In particular, the concept noosphere was introduced by P. Teilhard de Chardin and E. Le Roy to denote the mental shell of the globe, the formation of which is associated with the emergence and development of human consciousness. V.I. Vernadsky expanded the scientific scope of this concept and added that the noosphere is a new, higher stage of the biosphere, associated with the emergence and development of humanity, which, learning the laws of nature and improving technology, becomes a powerful force influencing terrestrial processes [5, p. 65]. Solid recent scientific researches became the basis in the study of cognitive linguistics (N. Boldyrev, Z. Popova, J. Sternin, M. Pimenova, J. Fauconnier, M. Turner, D. Newby) and linguoconceptology (D. Likhachev, A. Rusakova and O. Selivanova, Yu. Kravtsova).

The article aims to identify the semantic transitions of Indo-European meanings of lexemes truth, belief, faith, and mind; build a semantic structure of these lexical units, and explore the semantic connections between the concepts TRUTH and NOOSPHERE MIND.
Results and discussions. Conceptosphere is the specific organization of all ideas, associations, knowledge, evaluations, emotions, and human experiences of any experience (phenomenon, action, process, object) that exist in human consciousness or his mental world. [9, p. 47-48].

As N.N. Boldyrev mentions, concepts are the units of knowledge in which the results of cognition are realized and represented, the results of conceptualization as one of the relevant cognitive processes. These are units of conceptual content that a person identifies in the process of cognition in order to further transfer knowledge in the form of language or further accumulation, which involves their structural organization in the process of storage [2, p. 24].

In the "Short Dictionary of Cognitive Terms" E.S. Kubryakova defines concept as an explanation of the mental resources of consciousness, as well as the information structure that reflects the knowledge and experience of man; it is an operative semantic unit of memory, conceptual system and language of the brain (lingua mentalis), the whole view of the world reflected in the human psyche [6, p. 89-90].

Immersed deeper in the meaning of the processes of human consciousness, we can assume that the most critical cognitive process is the conceptualization of the world, and knowledge structures, called concepts, are the result of this process, understanding the acquired knowledge about the environment. These postulates no longer require proof and argumentation, as well as the fact that the concept, according to A.P. Babushkin, first of all, is a mental formation, a semantic unit of collective consciousness and at the same time a form of reflection of the culture in the consciousness of each individual [1, p. 51].

Firstly, we turn to the etymological meanings of the concept name TRUTH, which has already been considered in some works [10]. The lexeme truth comes from Proto Indo-European roots *tris and *drew-o (in Christianity the trinity: the Father, the Son and the Holy Spirit) which is a suffixal from Indo-European roots *deru-, *dreu- "to be firm, stable", "harmony, order". The semantics of "order and harmony" reconstructed in the meanings of the Indo-European root *dreu- syncretically related to the semantics of "faith, trust".

These semantic transitions of an image of stability, firmness, harmony and order in the symbolism of faith, trust reflect the fact that in pre-Christian cultures faith, stability associated with wood, and above all with such a sacred relic for many cultures, including Indo-European, like an oak, around which the ritual of sacrifice took place and other sacred magical acts were performed. We should also turn to the 
etymology of lexemes, which have the semantics of faith in the English language - belief, faith. Lexeme belief began to be used in the XII century in the Christian sense as "faith in this religion", replacing the Old English lexeme geleafa, which was also used in the meaning of "faith, trust". It was related to the West German form *galaubon "respect, trust" formed with the intense prefix *ga- and Indo-European root * leubh- "care, desire, love". The prefix *ga- was changed by analogy with the verb believe "to accept something as true or confirmed, to have a firm or wholehearted religious conviction or persuasion" [15]. Thus, first, the semantic transitions of the primary meanings of faith were connected, with "trust in God", for the direct expression of which the lexeme belief was used.

The following semantic connections of ideas about belief traced in the word faith, which meant "fidelity to the promise (later the religious concept of promise)"; "loyalty to man"; "honesty, truth", which was borrowed from Old French feid, foi "faith, trust, confidence". It was also derived from Latin fides "trust, faith, confidence", associated with the root of the verb fidere "trust", which reaches Indo-European form *bheidh- "trust, persuade".

The contemporary meanings of the researched name of the TRUTH concept in the English dictionaries "Oxford Advanced Learner's Dictionary", "Longman Dictionary of Contemporary English" are presented as follows: 1 . the true facts about something, rather than what is untrue, imagined, or guessed; 2. being true [uncountable] the state or quality of being true; 3. important ideas [countable, usually plural] formal an important fact or idea that is accepted as being true; 4 . in truth/in fact; 5 . if (the) truth be known/told used when telling someone the real facts about a situation, or your real opinion; 6 . (spoken) used when giving your personal opinion or admitting something (to tell (you) the truth); 7. nothing could be further from the truth used to say that something is definitely not true; 8 . the truth will out old-fashioned used to say that even if you try to stop people from knowing something, they will find out in the end [16, p. 12].

Additional lexico-semantic variants are fixed in "Collins English Dictionary": 1. the truth about something is all the facts about it, rather than things that are imagined or invented; 2 . if you say that there is some truth in a statement or story, you mean that it is true, or at least partly true; 3. a truth is something that is believed to be true; 4. moment of truth 'belief in the absolute truth' [11].

Simultaneously with the lexeme trust in English, its synonym belief functions with three lexico-se- mantic variants: 1 . faith; 2 . thought; 3 . as a religious concept [16, p. 100-101].

In modern explanatory dictionaries of the English language, the noun faith has five meanings with abstract, religious and moral-ethical semantics: 1) trust; 2) (religious) faith; 3) religion; 4) honest intentions; 5) loyalty, devotion [16, p. 453].

The lexeme belief as synonym of trust functions in three lexico-semantic variants: 1) a state or habit of mind in which trust or confidence is placed in some person or thing; 2) something that is accepted, considered to be accurate, or held as an opinion; 3 ) conviction of the truth of some statement or the reality of some being or phenomenon primarily when based on examination of evidence [13].

For a more comprehensive analysis of such a phenomenon as the truth, it is possible to interpret the term presented by lawyers. In their opinion, this term expresses: 1) the real state of affairs; 2) strict observance of the truth in bilateral agreements; 3 ) the complete and indisputable truth of the witness to establish the truth; 4) truth as the only and indisputable proof; 5) providing truth as evidence in the prosecution of defamation in certain circumstances (in the constitutions of the United States of America) [14].

Based on the identified lexico-semantic variants, we present generalized components of the semantic structure of the researched lexeme truth in English language: 1. presence of fact as something authentic/true; 2. recognition of fact as truth / authoritative opinion; 3 . justice; 4. belief in the truth; 5 . God.

The concept MIND, NOOSPHERE MIND in the English-speaking culture are inextricably linked with the consciousness and mental activity of a person.

The etymological meanings of lexeme mind comes from Proto Indo-European root *men- in a sense "to think" (online etymology), which, according to V.V. Levitskiy, passes into the Indo-European root *mann- with the meaning "man" and the version "a man who thinks", "intellectual man" (p. 373), Gothic gamunds "memory", "recollection", "thought", Old English gemynd "memory", "remembrance"; "thought"; "intellect" and "intention" [7, p. 396; 15]. In the late XII century the lexeme acquired lexical significance "something that can be felt", "thought, willed; the intellect". The meanings «"thinking process; mental and intellectual faculties" replenished the semantic structure of the word in XIII century. Such meanings as "attitude, spirits", "mental disposition", "view, opinion" and the last lexical and semantic variant "memory" are attested in XIV century.

Modern lexicographical sources such as Collins English Dictionary, Longman Dictionary of Contemporary English present the following seman- 
tic structure of the lexical unit mind: 1. in the sense of brain (the part of the person responsible for thought, feelings, and intention); 2 . in the sense of memory or recollection; 3 . in sense of attention or thoughts; 4. in the sense of intelligence as opposed to feelings or wishes; 5 . a person considered as an intellectual being; 6. an intention or desire; 7. a sound mental state; 8 . the condition or state of a person's feelings or thoughts $[11 ; 12]$.

The Merriam-Webster dictionary provides additional meanings of this lexeme: 1) a conscious substratum or factor in the universe and even 2) Chrisnotian science: the incorporeal divine Principle ruling over all as eternal Spirit: infinite Mind [13].

For a more comprehensive analysis of such a phenomenon as the mind, it is possible to interpret the term presented by psychologists. In their opinion and according to the American Psychological Association Dictionary of Psychology, this term expresses "all intellectual and psychological phenomena of an organism, encompassing motivational, affective, behavioural, perceptual, and cognitive systems", it also denotes "consciousness or awareness, particularly as specific to an individual; intention or volition; opinion or point of view" and "human consciousness regarded as an immaterial entity distinct from the brain".

Turning to the analysis of the concept NOOSPHERE MIND, we should note that the outstanding scientist V.I. Vernadskiy asserted that humanity is experiencing a bright entry into the planet's geological history. In the last millennia, there has been an intensive growth of the influence of civilized humankind on changes in the biosphere. Under the influence of scientific thought and human labour, the biosphere passes into a new state - the noosphere (borrowed from Greek word noo-, which means "intellect" and "mind"). Scientific knowledge itself, like a powerful geological force, creates the noosphere. Society is more potent, the more conscious it is. Every act is the more correct if it is in harmony with the common good and the brighter is the result of the work of the number of people who can think. The noosphere is the domain of thoughts enveloping the Earth.
Summarizing all suggested lexico-semantic variants, we could define the NOOSPHERE MIND as the sphere of human consciousness, mental activity, intellect, personal relationships, especially regarding its influence on the biosphere and relation to evolution [13]. All mentioned semes are semantic transformations of Indo-European roots with the meaning "to think", "to perceive with the senses, to understand", "intellectual man", which became the sources for the modern semantic structure.

As a result of the definitive analysis of the concept names TRUTH, MIND and NOOSPHERE MIND, it is possible to reveal certain semantic connections between them. Such semantic correlations are observed first of all in a common understanding of both concepts as "intellectual phenomenon encompassing motivational and cognitive systems", then semes "harmony", "order", "honest intentions", "desire", in a moral and spiritual component such as "religious concept" or "Christian science", "God". We also would like to articulate the idea that noosphere itself and NOOSPHERE MIND create new senses and values, however, in which there is a place for global universal human values among which there is TRUTH.

Conclusions. The dynamic changes that have manifested in the biosphere over the past thousand years in connection with the growth of scientific thought and the social activity of humanity have never been noted before. The human task is to deliver the most significant possible benefit to others. It becomes clear that the development of humanity can be achieved by various means, one of which is science. Any deed is correct and harmonious with the common good when it results from the work of many people who can think.

The noosphere mind combines ecological, global, universal and cultural values of civilized humanity, eliminating the opposition of man and nature, providing a stimulus to the moral and ethical evolution of planetary life in unity with nature. The modern anthropocosmic worldview denies the consumer's attitude to nature as an environment without which fundamental worldview values cannot be formed in every culture.

\section{REFERENCES:}

1. Бабушкин А.П. Типы концептов в лексико-фразеологической семантике языка, их личностная и национальная специфика : дисс. ... докт. филол. наук : 10.02.19. Воронеж, 1997. 330 с.

2. Болдырев Н.Н. О метаязыке когнитивной лингвистики: концепт как единица знания. Когнитивные исследования языка. Взаимодействие когнитивных структур : сборник научных трудов. 2011. Вып. IX. С. 23-32.

3. Вернадский В.И. Биосфрера и ноосфрера. Москва : Наука, 1989. 261 с.

4. Воркачев С.Г. Российская лингвокультурная концептология: современное состояние, проблемы, вектор развития. Известия РАН. Серия литературы и языка. 2011. Т. 70. № 5. С. 64-74.

5. Егорова М.А. «Когнитивное пространство» и его соотношение с понятиями «ментальное пространство», «когнитивная база», «концептосфера», «картина мира». Вестник ИГЛУ. Серия «Филология». 2012. № 3. C. 61-68. 
6. Краткий словарь когнитивных терминов / за ред. Е.С. Кубряковой. Москва : МГУ им. М.В. Ломоносова, 1997. 245 c.

7. Левицкий В.В. Этимологический словарь германских языков. Винница : Нова Книга, 2010. Т. 1. 616 с. ; T. 2. $368 \mathrm{c}$.

8. Прохоров Ю.Е. К проблеме «концепта» и «концептосферы». Язык, сознание, коммуникация : сборник статей. Москва : МАКС Пресс, 2005. Вып. 30. С. 74-94.

9. Рудакова А.В. Когнитология и когнитивная лингвистика. Воронеж : Изд-во ВГАУ, 2004. 80 с.

10. Стефранова Н.О. Реконструкція першозначень ціннісно-мотиваційного ядра концептів Істина і Правда. Науковий вісник Міжнародного гуманітарного університету. Одеса : Міжнародний гуманітарний університет, 2019. Вип. 41. Т. 2. С. 114-118.

11. Collins English Dictionary. URL: https://www.collinsdictionary.com/dictionary/english/truth.

12. Longman Dictionary of Contemporary English. URL: https://www.Idoceonline.com/dictionary/truth.

13. Merriam-Webster's Collegiate Dictionary. UK : Merriam-Webster Inc. 1998. 1664 p.

14. Law Dictionary and Black's Law Dictionary. URL: https://dictionary.thelaw.com.

15. Online etymology dictionary. URL: https://www.etymonline.com/.

16. Oxford Advanced Learner's Dictionary of Current English. Oxford University Press, 2000. 1540 p. 